\title{
DÜBLIN
}

Technological University Dublin

ARROW@TU Dublin

Articles

School of Food Science and Environmental

Health

2009

\section{Inactivation of Escherichia Coli in Orange Juice Using Ozone}

\author{
Sonal Patil \\ Technological University Dublin \\ Paula Bourke \\ Technological University Dublin, paula.bourke@tudublin.ie \\ Jesus Maria Frias \\ Technological University Dublin, Jesus.Frias@tudublin.ie
}

See next page for additional authors

Follow this and additional works at: https://arrow.tudublin.ie/schfsehart

Part of the Food Microbiology Commons

\section{Recommended Citation}

Patil, S., Bourke, P., Frias, J., Tiwari, B., Cullen, P. J., : Inactivation of Escherichia coli in orange juice using ozone, Innovative Food Science and Emerging Technologies, Vol. 10, Iss. 4, Oct. 2009. pp. 551 - 557

http://dx.doi.org/10.1016/j.ifset.2009.05.011

This Article is brought to you for free and open access by the School of Food Science and Environmental Health at ARROW@TU Dublin. It has been accepted for inclusion in Articles by an authorized administrator of ARROW@TU Dublin. For more information, please contact arrow.admin@tudublin.ie, aisling.coyne@tudublin.ie, gerard.connolly@tudublin.ie.

Funder: National Development Plan, Dept of Agriculture, Food \& Fisheries 


\section{Authors}

Sonal Patil, Paula Bourke, Jesus Maria Frias, Brijesh Tiwari, and Patrick Cullen 


\title{
Title: "Inactivation of Escherichia coli in orange juice using ozone"
}

\author{
S. Patil ${ }^{1}$, P. Bourke* ${ }^{1}$, J. Frias ${ }^{1}$, B. Tiwari ${ }^{2}$ and P.J. Cullen ${ }^{1}$ \\ ${ }^{1}$ School of Food Science and Environmental Health, Dublin Institute of Technology, \\ Cathal Brugha Street, Dublin 1, Ireland \\ ${ }^{2}$,School of Agriculture, Food Science \& Veterinary Medicine, University College Dublin, Belfield, \\ Dublin 4, Ireland
}

*Corresponding author. Tel: +353-14027594; Fax: +353-14024495; E-mail: paula.bourke@ dit.ie 


\section{Abstract}

This research investigated the efficacy of gaseous ozone for the inactivation of Escherichia coli ATCC 25922 and NCTC 12900 strains in orange juice. Orange juice inoculated with E. coli $\left(10^{6} \mathrm{CFU} \mathrm{mL}^{-1}\right)$ as a challenge microorganism was treated with ozone at $75-78 \mu \mathrm{g} \mathrm{mL} \mathrm{m}^{-1}$ for different time periods $(0-18 \mathrm{~min})$. The efficacy of ozone for inactivation of both strains of $E$. coli was evaluated as a function of different juice types: model orange juice, fresh unfiltered juice, juice without pulp, and juice filtered through $500 \mu \mathrm{m}$ or $1 \mathrm{~mm}$ sieves. Fast inactivation rates for total reduction of E. coli were achieved in model orange juice (60 seconds) and in juice with low pulp content (6 min). However, in unfiltered juice inactivation was achieved after 15-18 min. This indicated that juice organic matter interferes with antibacterial activity of gaseous ozone. The effect of prior acid ( $\mathrm{pH}$ 5.0) exposure of E. coli strains on the inactivation efficacy of ozone treatment was also investigated. There was a strain effect observed, where prior acid exposure resulted in higher inactivation times in some cases by comparison with the control cells. However, the overarching influence on inactivation efficacy of ozone was related to the pulp content. Generally, the applied gaseous ozone treatment of orange juice resulted in a population reduction of $5 \log$ cycles.

Key words: Escherichia coli, ozone, non-thermal inactivation, acid exposure, orange juice, microbial kinetics

Industrial relevance: To facilitate the preservation of unstable nutrients many juice processors have investigated alternatives to thermal pasteurisation, including unpasteurised short shelf life juices with high retail value. This trend has continued within the European Union. However within the US recent regulations by the FDA have 
required processors to achieve a 5-log reduction in the numbers of the most resistant pathogens in their finished products. Pathogenic E. coli may survive in acid environments such as fruit juices for long periods. This study demonstrates that the use of ozone as a non-thermal technology is effective for inactivation of E. coli and acid exposed E. coli in orange juice. Information on the design of the ozone treatment for inactivation of E. coli which results into safe juice products is also among the main outputs of this work. Ozone auto-decomposition makes this technology safe for fruit juice processing. 


\section{Introduction}

Fruit juices are an important source of bioactive compounds such as phenolics (e.g flavanone glycosides, hydroxycinnamic acids), vitamin $\mathrm{C}$ and carotenoids (Abeysinghe, Li, Sun, Zhang, Zhou \& Chen, 2007), but technologies used for their processing and subsequent storage may cause alterations in their contents so they may not provide the benefits expected by the consumer. Fruit juice producers have traditionally relied on the acidity of their products to assure microbiological safety. Nevertheless, several incidents of food borne disease have been associated with juices. In 1991, an outbreak of Escherichia coli $\mathrm{O} 157: \mathrm{H7}$ infections and hemolytic uremic syndrome was linked to traditionally pressed apple cider. In United States 21 juice-associated outbreaks reported to the CDC (Centers for Disease Control and Prevention) between 1995 and 2005 (Vojdani, Beuchat \& Tauxe, 2008). Recent outbreaks have shown that fruit juices can be vehicles for food borne pathogens (CDC, 1996, 1999). E. coli O157:H7 is an enteric pathogen with a low infectious dose, which usually causes hemorrhagic colitis, but has also the potential to cause hemolytic uremic syndrome in young children and the immunocompromised (Boyce, Swerdlow \& Griffin, 1995).

These outbreaks led the United States Food and Drug administration (FDA) to issue hazard analysis and critical control points (HACCP) regulations for safe and sanitary processing of juice (USFDA, 2001). A primary performance standard is a minimum 5-log reduction of the pathogens of concern in the juice being processed (USFDA, 2001). A common method for preservation and processing of fruit juices is pasteurisation. Thermal pasteurisation of orange juice can cause degradation of the product's quality (non-enzymatic browning and off-flavours production), while the fresh juice flavour 
(Basak \& Ramaswamy, 1996) may be impaired and its vitamin content decreased. In recent years consumers have increasingly sought ready-to-use 'fresh-like' products, which are usually refrigerated. This has led the food industry to develop alternative processing technologies in order to produce foods with a minimum of nutritional, physicochemical, or organoleptic changes (Esteve \& Frigola, 2007). Consumers tend to prefer recently extracted fresh juices with fresh taste and minimal flavour or vitamin losses (Bignon, 1997). The FDA's approval of ozone as a direct additive to food in 2001 triggered interest in ozone applications. A number of commercial fruit juice processors in the US and Europe began employing ozone for pasteurisation resulting in the issue of industry guidelines. These guidelines (FDA, 2004) highlight gaps in the literature with respect to the critical control parameters of ozone during microbial inactivation in liquid systems.

Ozone is a triatomic allotrope of oxygen and is characterized by a high oxidation potential that conveys bactericidal and viricidal properties (Burleson, Murray \& Pollard, 1975; Kim, Yousef \& Dave, 1999). Ozone inactivates microorganisms through oxidisation and residual ozone decomposes to nontoxic products (i.e., oxygen) making it an environmentally friendly antimicrobial agent for use in the food industry (Kim et al., 1999). Restaino et al. (1995) determined that ozone effectively killed Gram-positive bacteria such as Listeria monocytogenes, Staphylococcus aureus, Bacillus cereus, Enterococcus faecalis, and Gram-negative bacteria including Pseudomonas aeruginosa, and Yersinia enterocolitica in deionized water in the absence or presence of organic material such as soluble starch (SS) and bovine serum albumin (BSA). Ozone has been shown to reduce populations of E. coli O157:H7 in phosphate buffer (Byun, Kwon, Yook 
\& Kim, 1998) while its preservation efficacy has been also evaluated in a variety of food products, including milk, gelatin, albumin, casein, and meat products (Kim et al., 1999). The antibacterial activity of ozone has been attributed to its diffusion capability (Hunt \& Marinas, 1997). It reacts up to 3000 times faster than chlorine with organic material, and it readily diffuses through biological cell membranes.

Microorganisms can induce adaptation responses to environmental stresses by expressing specific sets of genes on exposure to acid, salt, heat, cold, reactive oxygen species, starvation etc. Therefore it is of great importance to evaluate the efficiency of food preservation treatments using resistant strains while developing process criteria (Johnson, 2003). The objectives of this study were (i) to determine the efficacy of continuous gaseous ozone treatment for reduction of two different strains of E. coli at ambient temperature $\left(12-15^{\circ} \mathrm{C}\right)$ in orange juice, (ii) to evaluate how inactivation was affected by the orange juice pulp content and (iii) to investigate if prior acid exposure of the challenge microorganism significantly impacted on treatment efficacy.

\section{Materials and Methods}

\subsection{Bacterial strains and cultural conditions}

Two strains of E. coli were used in this study: E. coli ATCC 25922 (generic strain), obtained from microbiology stock culture of the School of Food Science and Environmental Health of the Dublin Institute of Technology, and E. coli NCTC 12900 (non-toxigenic strain of E. coli O157:H7), obtained from National Collection of Type Cultures of the Health Protection Agency (London, UK). Both strains were used for inactivation studies to ensure potential useful effects against this key pathogen of concern 
to fruit juice processors were measured. The bacteria were maintained as frozen stocks at $-70^{\circ} \mathrm{C}$ in the form of protective beads, which were plated onto tryptic soy agar (TSA, Scharlau Chemie) and incubated overnight at $37^{\circ} \mathrm{C}$ to obtain single colonies before storage at $4{ }^{\circ} \mathrm{C}$. Working cultures were prepared by inoculating a single colony into tryptic soya broth (TSB, Scharlau Chemie) and incubating overnight at $37^{\circ} \mathrm{C}$ (Cheng, Yu \& Chou, 2003; Caggia, Ombretta Scifò, Restuccia \& Randazzo, 2009) .

\subsection{Preparation of model orange juice (MOJ)}

The MOJ medium of Shinoda, Murata, Homma, and Komura (2004) without modifications was used in the experiments. The composition of MOJ per $100 \mathrm{~mL}$ was as follows: sucrose: $5.0 \mathrm{~g}$; glucose: $2.5 \mathrm{~g}$; fructose: $2.5 \mathrm{~g}$; citric acid: $1.0 \mathrm{~g}$; ascorbic acid: 30 mg; L-serine: 7.0 mmol; L-asparagine: 5.4 mmol, L-alanine: $1.9 \mathrm{mmol}$; L-arginine: 0.75 mmol; L-glutamic acid: $0.54 \mathrm{mmol}$; L-proline: $0.42 \mathrm{mmol}$. The $\mathrm{pH}$ of MOJ was adjusted to $\mathrm{pH} 3.0$ using $1 \mathrm{~N} \mathrm{NaOH}$. MOJ was then sterilized at $121^{\circ} \mathrm{C}$ for $15 \mathrm{~min}$.

\subsection{Preparation of orange juice}

\subsubsection{Fresh orange juice unfiltered}

Oranges (variety: Balady, Egypt) were purchased from a local market, washed with tap water and cut into two pieces. The fresh oranges were squeezed with fruit juicer (Rowenta NEO type 8332). All juice preparations were stored at $4{ }^{\circ} \mathrm{C}$. The $\mathrm{pH}$ was measured using a pH meter with a glass electrode (Orion Model, England) and was in the range of 3.5-4.0.

\subsubsection{Fresh orange juice filtered (without pulp)}


Juice without pulp was prepared as above with centrifugation (SIGMA 2K15, Bench Top Refrigerated Ultracentrifuge, AGB scientific LTD) at $13000 \mathrm{rpm}$ for $10 \mathrm{~min}$ followed by filtering the juice through Whatman No.1 filter paper, giving a $75 \%$ yield in terms of filtrate.

\subsubsection{Fresh orange juice with reduced pulp content}

Juice with reduced pulp was prepared as above and submitted to a finishing process by passing through sieves (Laboratory test sieve, Retsch, Germany) to reduce the pulp content. Two different sieve sizes were employed to obtain juice with different pulp

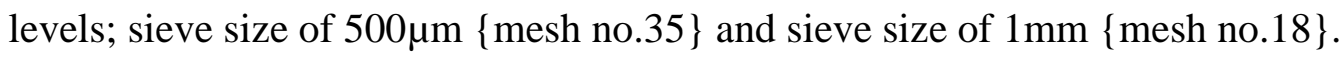

\subsection{Preparation of cell suspensions}

Cells grown in TSB were harvested by centrifugation at $10,000 \mathrm{rpm}$ for $10 \mathrm{~min}$ at $4{ }^{\circ} \mathrm{C}$. The cell pellet was washed twice with sterile phosphate buffered saline (PBS, Oxoid LTD, UK). The pellet was re-suspended in PBS and the bacterial density was determined by measuring absorbance at $550 \mathrm{~nm}$ using McFarland standard (BioMérieux, Marcy l'Etoile, France) to allow a working inoculum corresponding to $1.0 \times 10^{8} \mathrm{CFU} \mathrm{mL}^{-1}$ to be prepared. This was then serially diluted in maximum recovery diluent (MRD, Scharlau Chemie) to obtain approximately $10^{7} \mathrm{CFU} \mathrm{mL}^{-1}$. Adding $10 \mathrm{~mL}$ of cell concentration $\left(10^{7}\right.$

$\mathrm{CFU} \mathrm{mL}{ }^{-1}$ ) to $90 \mathrm{~mL}$ of orange juice yielded a final concentration of $10^{6} \mathrm{CFU} \mathrm{mL}^{-1}$. For model orange juice samples, the pellet was re-suspended in PBS and diluted into MOJ to yield the same final concentration.

\subsection{Acid exposure of bacterial cultures}


Cells were exposed to hydrochloric acid $(\mathrm{HCl})$ as described by Cheng, $\mathrm{Yu}$ and $\mathrm{Chou}$ (2003). Acid stress conditions were imposed for two time periods; 1 hour and 18 hours. Working cultures were grown overnight in TSB at $37^{\circ} \mathrm{C}$. Cells were then harvested by centrifugation at $10,000 \mathrm{rpm}$ for $10 \mathrm{~min}$ at $4^{\circ} \mathrm{C}$. The cell pellet was washed twice with sterile PBS, re-suspended in $10 \mathrm{~mL}$ TSB (pH5.0, adjusted with $6 \mathrm{~N} \mathrm{HCl}$, at ambient temperature of $12-15{ }^{\circ} \mathrm{C}$ ) and incubated at $37{ }^{\circ} \mathrm{C}$ for $1 \mathrm{~h}$. For a 18 -h acid exposure, bacterial strains were grown directly in $\mathrm{TSB}(\mathrm{pH} 5.0)$ at $37^{\circ} \mathrm{C}$. After incubation, cultures were diluted in MRD ( $\mathrm{pH}$ 5.0) to yield approximately $10^{7}$ cells $\mathrm{mL}^{-1}$, with further dilution in orange juice to a final concentration of $10^{6} \mathrm{CFU} \mathrm{mL}^{-1}$.

\subsection{Ozone treatment}

Ozone gas was generated using an ozone generator (Model OL80, Ozone services, Canada, Figure 1) in a $100 \mathrm{~mL}$ glass bubble column. Ozone was produced by a corona discharge generator. Pure oxygen was supplied via an oxygen cylinder (Air Products Ltd., Dublin, Ireland) and the flow rate was controlled using an oxygen flow regulator. A previously determined optimum flow rate of $0.12 \mathrm{~L} \mathrm{~min}^{-1}$ with an ozone concentration of 75-78 $\mu \mathrm{g} \mathrm{mL}^{-1}$ was applied for each treatment (Patil, Cullen, Kelly, Frias \& Bourke, 2009). Ozone concentration was recorded using an ozone analyzer (built in ozone module OL80A/DLS, Ozone services, Burton, Canada). Excess ozone was destroyed by an ozone destroyer unit. To prevent excess foaming, $20 \mu \mathrm{l}$ sterile anti-foaming agent (Antifoam B emulsion, Sigma Aldrich, Ireland Ltd.) was added before each ozone treatment. Two bacterial strains (E. coli ATCC 25922, E. coli NCTC 12900) were investigated for their response to ozone treatment. Experiments were performed with non-acid exposed control 
cultures as well as a range of acid exposed cultures; namely $1 \mathrm{~h}$, and $18 \mathrm{~h}$ acid exposed cultures. Unfiltered juice was treated for 30 minutes with sampling at 3 min intervals. All other juices were treated for 6-7 minutes with sampling at 1 min intervals. All experiments were carried out in duplicate and replicated at least twice.

\subsection{Microbiological analysis}

The efficacy of treatments was determined in terms of reduction in viable counts over time. Populations of challenge organism were determined by plating onto both TSA and selective media, Sorbitol MacConkey agar (SMAC, Scharlau Chemie) respectively. Samples (1mL aliquots) were withdrawn from treated juice at specific time intervals, serially diluted in MRD and $0.1 \mathrm{~mL}$ aliquots of appropriate dilutions were surface plated on TSA and SMAC to compare recovery of E. coli strains. Plates were incubated at $37^{\circ} \mathrm{C}$ for $24 \mathrm{~h}$ and then counted. Results were reported as $\log { }_{10} \mathrm{CFU} \mathrm{mL}^{-1}$. Data were pooled and average values and standard deviations determined. Means were compared using ANOVA followed by LSD testing at $\mathrm{p}<0.05$ level (SPSS, version 15.0).

\subsection{Inactivation kinetics}

The GInaFiT tool was employed to perform the regression analysis of the microbial inactivation data (Geeraerd, Valdramidis \& Van Impe, 2005). The Weibull model was used to analyze the data:

$$
\log _{10}(N)=\log _{10}\left(N_{0}\right)-\left(\frac{t}{\delta}\right)^{p}
$$

where $N$ is the number of microorganisms, $N_{0}\left(\mathrm{CFU} \mathrm{mL} \mathrm{m}^{-1}\right)$ is the initial number of microorganisms, $\delta$ [min] (time for the first decimal reduction) and $p[-] \square$ are parameters related to the scale and shape of the inactivation curve, respectively. The Weibull 
distribution corresponds to a concave upward survival curve if $\mathrm{p}<1$ and concave downward if $\mathrm{p}>1$ (Van Boekel, 2002).

The numerical values of $\delta$ and $p$ were used to calculate a desired log reduction. The time required to obtain an $x \log$ reduction $\left(\mathrm{t}_{\mathrm{xd}}\right)$ was calculated using equation 2 . For this case study $x$ was equal to 5, following the regulation of USFDA for a minimum 5-log reduction in the juice being processed (USFDA 2001).

$$
t_{x d}=\delta \times(x)^{\frac{1}{p}}
$$

\section{Results}

\subsection{Effect of ozone inactivation of E. coli in model orange juice}

Ozone inactivation of both $E$. coli strains in model orange juice was rapid in this low $\mathrm{pH}$ medium. Ozone treatment at the optimum flow rate of $0.12 \mathrm{~L} \min ^{-1}$ with an ozone concentration of $75-78 \mu \mathrm{g} \mathrm{mL} \mathrm{m}^{-1}$ resulted in a $6.0 \mathrm{log}$ cycle reduction within 60 seconds.

\subsection{Effect of ozone on inactivation of E. coli in orange juice}

The Weibull parameters $\delta$ and $p$ are shown in Table 1 . In the present study, the shape parameter $p \square$ showed downward concavity for both E. coli strains (Fig. 2 and 3). The inactivation of $E$. coli in orange juice was fitted using the Weibull model, which provided estimations of microbial inactivation in terms of processing time required. The $\mathrm{R}^{2}$ values of 0.93 and above (Table 1) show that the Weibull model was a good fit for the experimental data analysed. $p$ values $>1$ indicate the susceptibility of the remaining cells to the treatment (van Boekel, 2002). 
The efficacy of ozone was found to depend both on the juice type and the bacterial strain (statistical indices of $\mathrm{p}<0.05$ ). Both strains of $E$. coli studied (E. coli ATCC 25922, E. coli NCTC 12900) were sensitive to ozone ( $\mathrm{p}<0.05)$. In unfiltered juice, ATCC 25922 and NCTC 12900 were completely inactivated after 18 and 15 min respectively (Fig. 2 and 3) as determined on TSA and SMAC. However, ozone treatment of ATCC 25922 in orange juice without pulp and juice passed through the $500 \mu \mathrm{m}$ sieve, resulted in complete inactivation within 5 min (Fig.2). The population of E. coli 25922 in juice passed through sieve of $1 \mathrm{~mm}$ diameter decreased by 6.0 log cycles in 6 min treatment time (Fig.2). Similarly, ozone treatment of NCTC 12900 in orange juice without pulp and juice passed through the $500 \mu \mathrm{m}$ sieve resulted in complete inactivation in 5 and $6 \mathrm{~min}$, respectively (Fig.3). NCTC 12900 decreased by 4.6 and $6.0 \log$ cycles after 6 min treatment time in juice passed through the $1 \mathrm{~mm}$ sieve as determined on TSA and SMAC, respectively.

The $t_{5 d}\left(t_{5 d}\right.$ - the time required for a $5 \log$ reduction) for both $E$. coli strains in the different juice types are shown in Table 1 . The $t_{5 d}$ values were lower as the amount of pulp present in the orange juice decreased $(\mathrm{p}<0.05)$. The inactivation of $E$. coli strains in unfiltered juice showed higher $t_{5 d}$ values compared to the other juice types. 3.3 Effect of acid exposure on treatment efficacy

The effect of acid exposure on ozone treatment efficacy was evaluated in orange juice passed through a $1 \mathrm{~mm}$ sieve. Ozone inactivation curves for acid-exposed E. coli cells at the different acid exposure conditions are shown in Figure 4. For acid exposed E. coli strains the shape parameter $p$ showed downward concavity. The $p$ values for $1 \mathrm{~h}$ acid exposed cells were lower by comparison with both the $18 \mathrm{~h}$ acid exposed and control 
populations (Table 2), indicating a lower susceptibility to the treatment with a short period of acid adaptation.

Ozone treatment of $1 \mathrm{~h}$ acid exposed E. coli ATCC 25922 resulted in a reduction of 4.8 and $5.5 \log$ cycles after 7 min treatment time on TSA and SMAC, respectively. However, ozone treatment of $1 \mathrm{~h}$ acid exposed E. coli NCTC 12900 reduced an initial count of log 6.28 CFU mL $\mathrm{m}^{-1}$ to below detectable levels after 7 min treatment time on TSA and SMAC, respectively. However, with the $18 \mathrm{~h}$ acid exposed cells, populations of E. coli ATCC 25922 and E. coli NCTC 12900 were decreased by 6.0 and 5.3 log cycles respectively within $7 \mathrm{~min}$ as determined by using TSA. Similar trends were observed using SMAC where $18 \mathrm{~h}$ acid exposed E. coli ATCC 25922 and E. coli NCTC 12900 were decreased by 5.8 and $5.1 \log$ cycles, respectively. The $t_{5 d}$ values of the acid exposed E. coli strains are shown in Table 2. There was a strain difference observed between acid exposed and control populations. The estimated time for a $5 \mathrm{log}$ reduction of control (non-acid exposed) E. coli NCTC 12900, was 6.14 min, while the estimate for the generic strain $E$. coli ATCC 25922 was $5.62 \mathrm{~min}$. When the strains were subjected to a $1 \mathrm{~h}$ acid exposure, the estimated time required for a $5 \log$ cycle reduction in E. coli ATCC 25922 increased to $6.46 \mathrm{~min}$, while there was no similar increase for E. coli NCTC 12900. Conversely, following $18 \mathrm{~h}$ acid exposure, the estimated time required for a $5 \log$ cycle reduction in $E$. coli NCTC 12900 increased to 6.84 min, while the estimated time for E. coli ATCC 25922 was similar to that recorded for the control cells. However, there was a significant difference observed for E. coli ATCC 25922 between 1-h acid exposed population compared to the control and 18-h acid exposed population ( $p>0.05$ ); whereas there was 
no significant difference observed between control population of E. coli NCTC 12900 and those exposed to acid conditions for $1 \mathrm{~h}$ or $18 \mathrm{~h}$.

\section{Discussion}

The direct application of ozone was found to be effective for the inactivation or reduction of E. coli in orange juice (Figures 2, 3 and 4), but the rate was dependant on the juice type used. In the present study inactivation in unfiltered juice was achieved after 15-18 min treatment time by comparison with significantly shorter inactivation times within model orange juice or juice with low pulp content. This could be ascribed to the organic compounds such as sugars, fibres, ascorbic acid, present in orange juice which could affect the dissolution rate of ozone in the system, thereby reducing the ozone level available for inactivation of $E$. coli cells. The organic load present within the medium is known to decrease the effectiveness of ozone for the inactivation of microorganisms. Williams, Sumner and Golden (2005), observed a reduced efficacy of ozonation for inactivation of $E$. coli in orange juice in the presence of ascorbic acid and organic matter and Mielcke and Ried (2004), also reported that a high and persistent level of organic substances will have a negative impact on the ozone disinfection rate. The effectiveness of ozone against microorganisms depends not only on the amount applied, but also on the residual ozone in the medium, various environmental factors such as medium $\mathrm{pH}$, temperature, humidity, additives (surfactants, sugars, etc.), and the amount of organic matter surrounding the cells (Pascual, Liorca \& Canut, 2007). The focus of this study was to evaluate the impact of organic matter during ozone processing. However, the effect of residual ozone for the specific flow rate and ozone concentration levels employed was 
evaluated in apple juice, where non-significant microbial reduction was observed (Data not shown).

The type of organic material may impact ozone efficacy more than the amount of organic material present (Restaino, Frampton, Hemphill \& Palnikar, 1995). This is in agreement with Guzel-seydim, Bever and Greene (2004), who observed that the presence of food components such as caseinate in whipping cream provided a high level of protection to the bacterial populations against ozone treatment, whereas locust bean gum resulted in an intermediate level of protection. In the present study, fast inactivation rates were achieved in the model orange juice and the filtered juices which may be attributed to the absence of high ozone demanding substances. Komanapalli and Lau (1998) found that the cidal activity of ozone was greatly affected by the dose applied, the presence of ozonequenching proteins, and the type of challenge microorganisms. Williams et al., (2004) reported E. coli $\mathrm{O} 157: \mathrm{H} 7$ was inactivated in orange juice after a 75 min ozone treatment applied at ambient temperature, while in the present study faster inactivation rates within a period of 6 to $18 \mathrm{~min}$ were achieved. The possible reason for this could be the different ozone system as well as the different control parameters (i.e., flow rate of of $2.4 \mathrm{~L} \mathrm{~min}^{-1}$ and ozone concentration of $0.9 \mathrm{~g} \mathrm{~h}^{-1}$ ) that were used for the Williams et al., (2004) inactivation studies. In the present study, a previously optimized ozone flow rate was used which was lower than that employed by Williams et al., (2004). Flow rate was previously determined to be a critical factor, at high flow rates a small number of large bubbles are produced, which rise to the liquid surface quickly, thereby escaping the medium quickly. The resulting poor gas dissolution reduces the contact time, leading to a lower inactivation rate (Patil et al., 2009). The antibacterial efficacy of ozone was greater 
when target microorganisms were suspended in pure water or simple buffers than in complex systems (Khadre, Yousef \& Kim, 2001). The mechanism for inactivation of microorganisms by ozone is due to its high oxidation-reduction potential. Ozone is capable of oxidizing the constituent elements of microbial cell walls before penetrating inside the organism and oxidizing certain essential components such as unsaturated lipids, proteins, enzymes and nucleic acids. When a large part of the membrane barrier is destroyed, it causes lysis and leakage of bacterial cells and results in their immediate destruction (Muthukumarappan, O’Donnell \& Cullen, 2008). Decreasing $\mathrm{pH}$ and temperature are associated with increasing stability of ozone molecules (Kim et al., 1999). Tiwari, O'Donnell, Muthukumarappan \& Cullen (2009) recently studied the effects of ozone on quality and nutritional parameters for a range of fruit juices, highlighting significant losses in nutritional quality which were dependent on ozone control parameters of ozone concentration and gas flow rate. However, achieving rapid microbial inactivation using optimised control parameters may mitigate losses in nutritional quality.

When microorganisms are stressed, an adaptive response may follow which can increase the organisms' tolerance to the same or to a different type of stress (Yousef \& Courtney, 2003). Many bacteria react to stress by inducing the synthesis of various proteins (Herendeen, Vanbogelen \& Neidhardt, 1979; Jones \& Inouye, 1994). Buchanan and Edelson (1999), reported a cross protective effect of acid shocking and acid adaptation of enterohaemorrhagic E. coli (EHEC) against heat or other stresses but also observed that the determination of survival of EHEC in acidic foods should consider the strain and its ability to induce stress responses. The resistance or adaptation of 
microorganisms to acid conditions can have implications for food safety. Additionally, Johnson (2003) observed that challenge studies in food systems are required to adequately assess growth or survival of pathogens. The acid adaptation responses of food borne pathogens were previously examined at different $\mathrm{pH}$ conditions and $\mathrm{pH}$ 5.0-5.5 lead to the highest level of acid resistance for E. coli O157:H7 (Koutsoumanis \& Sofos, 2004). In this study both E. coli strains were subjected to acid exposure at pH 5.0 to examine the effect of prior acid exposure on the efficacy of ozone treatment in orange juice. Increased inactivation time of acid exposed E. coli cells of both strains to ozone treatment over the control cells was observed in the present study. The $t_{5 d}$ values of acid exposed $E$. coli cells were higher than the $t_{5 d}$ values of control cells in some cases. Acid exposure of E. coli ATCC 25922 for 1h and longer acid exposure (18h) for NCTC 12900 resulted in increased acid resistance, potentially giving a cross - protective effect against ozone treatment. Treatment of E. coli $\mathrm{O} 157: \mathrm{H} 7$ with acid has been reported to increase acid resistance after exposure to moderate acid environments (Kroll \& Patchett, 1992; Leyer, Wang \& Johnson, 1995) and was also shown to confer cross resistance to salt and heat (Rowe \& Kirk, 1999). In beef processing, prior acid adaptation negatively influenced the efficacy of a $2 \%$ acetic acid decontamination treatment for reduction of $E$. coli $\mathrm{O} 157: \mathrm{H} 7$ on carcasses (Berry \& Cutter, 2000) and acid adaptation prolonged the survival of E. coli $\mathrm{O} 157: \mathrm{H7}$ in various food systems, including apple cider, sausages (Leyer et al, 1995) and acid fruit juice (Hsin-Yi \& Chou, 2001).

Acid habituation of pathogens may enhance survival in acidic food (e.g. fruit juice) or in the stomach and subsequently cause infection after ingestion (Goodson \& Rowbury, 1989). In an environment with changing $\mathrm{pH}$, acid sensitive E. coli $\mathrm{O} 157$ 
cultures can become acid-resistant within 17 min (de Jonge, Takumi, Ritmeester \& van Leusden, 2003). Acid resistance and survival of pathogens have significant implications for food safety and the virulence of pathogenic microorganisms and the ability of nonacid adapted E. coli $\mathrm{O} 157$ to adapt within a very short period under extreme conditions further contribute to their virulence (Beales, 2004). Our results also showed that the extent of increased acid resistance varied with the strain and acid exposure conditions. When E. coli ATCC 25922 was acid exposed for $1 \mathrm{~h}$, an increased resistance to ozone treatment was observed. In the case of E. coli NCTC 12900 only the longer acid exposure time (18h) showed an increased $t_{5 d}$ value compared to the control cells. However, while increased resistance of acid stressed E. coli cells to ozone treatment was observed, $5 \log$ cycle reductions in populations were still achieved in less than $7 \mathrm{~min}$. Buchanan, Edelson and Boyd (1999) also reported that while pH during exposure had little effect on survival of E. coli $\mathrm{O} 157: \mathrm{H} 7$, acid-resistance consistently enhanced radiation resistance. Therefore, acid resistance should be considered when determining $t_{5 d}$ values in foods. Additional studies could be conducted in order to further elucidate the role of strains and stress exposure time on the inactivation efficacy of direct ozone treatments. Such studies could include comparison of the behaviour of acid-stressed E. coli strains with that of unadapted control cells in orange juice, through measurement of the in vivo expression of stress-related genes.

\section{Conclusions}

This work has shown that direct ozone treatment can be used to inactivate $E$. coli in orange juice. The efficacy of ozone treatment was found to be a function of juice type, strain of E. coli and duration of acid exposure conditions. Inactivation times for a $5 \log$ 
cycle reduction ranged between $60 \mathrm{sec}$ and $18 \mathrm{~min}$. Therefore ozone treatment could be used as a potential alternative to traditional thermal pasteurization for control of $E$. coli populations as a safety issue in fresh orange juice.

\section{Acknowledgement}

Funding for this research was provided under the National Development Plan 2000-2006, through the Food Institutional Research Measure, administered by the Department of Agriculture, Fisheries \& Food, Ireland.

\section{References}

Abeysinghe, D., Li, X., Sun, C., Zhang, W., Zhou, C., \& Chen, K. (2007). Bioactive compounds and antioxidant capacities in different edible tissues of citrus fruit of four species. Food Chemistry, 104(4), 1338-1344.

Basak, S.,\& Ramaswamy, H. S. (1996). Ultra high pressure treatment of orange juice: A kinetic study on inactivation of pectin methyl esterase. Food Research International, 29(7), 601-607.

Beales, N. (2004). Adaptation of microorganisms to cold temperatures, weak acid preservatives, low $\mathrm{pH}$, and osmotic stress: a review. Comprehensive Reviews in Food Science and Food Safety, 3 (1), 1-20.

Berry, E. D., \& Cutter, C. N. (2000). Effects of acid adaptation of Escherichia coli O157: H7 on efficacy of acetic acid spray washes to decontaminate beef carcass tissue. Applied and Environmental Microbiology, 66, 1493-1498.

Bignon, J. (1997). Cold pasteurizers Hyperbar for the stabilization of fresh fruit juices. Fruit processing, 6(2), 46-48. 
Boyce, T. G., Swerdlow, D. L., \& Griffin, P.M. (1995). Escherichia coli O157:H7 and the haemolytic uremic syndrome. The New England Journal of Medicine, 333, 364-368. Buchanan, R., \& Edelson, S. (1999). pH-dependent, stationary phase acid resistance response of enterohemorrhagic Escherichia coli in the presence of various acidulants. Journal of Food Protection, 62, 211-218.

Buchanan, R., Edelson, S. G., \& Boyd, G. (1999). Effects of pH and acid resistance on the radiation resistance of enterohemorrhagic Escherichia coli. Journal of Food Protection, 62, 219-228.

Burleson, G. R., Murray, T., M., \& Pollard, M. (1975). Inactivation of viruses and bacteria by ozone with and without sonication. Applied Microbiology, 29, 340-344.

Byun, M., Kwon, O., Yook, H., \& Kim, K. (1998). Gamma irradiation and ozone treatment for inactivation of Escherichia coli $\mathrm{O} 157: \mathrm{H} 7$ in culture media. Journal of Food Protection, 61, 728-730.

CDC (Centres for Disease Control and Prevention). (1996). Outbreak of Escherichia coli O157:H7 infections associated with drinking commercial unpasteurised apple juiceBritish, Colombia, California, Colorado, and Washington, October 1996. Morbidity Mortality Weekly Report, 45, 975.

CDC (Centres for Disease Control and Prevention). (1999). Outbreak of Salmonella serotype Muenchen infections associated with unpasteurised orange juice-United states and Canada, June 1999. Morbidity Mortality Weekly Report, 48, 582-585. Available at http://www.cdc.gov/mmwr/preview/mmwrhtml/mm4827a2.htm 
Cheng, H.Y., Yu, R., C., \& Chou, C.C. (2003). Increased acid tolerance of Escherichia coli $\mathrm{O} 157: \mathrm{H} 7$ as affected by acid adaptation time and conditions of acid challenge. Food Research International, 36, 49-56.

De Jonge, R., Takumi, K., Ritmeester, W, S., \& van Leusden, F, M. (2003). The adaptive response of Escherichia coli $\mathrm{O} 157$ in an environment with changing pH. Journal of Applied Microbiology, 150, 348-357.

Esteve M.J., \& Frígola A. (2007). Refrigerated fruit juices: quality and safety issues. Advances in Food Nutrition Research, 52,103-39

FDA. (2004). FDA Guidance to Industry, 2004: Recommendations to Processors of Apple Juice or Cider on the Use of Ozone for Pathogen Reduction Purposes. Available online <http://www.cfsan.fda.gov/ dms/juicgu13.html>.

Geeraerd, A.H., Valdramidis, V. P., \& Van Impe, J.F. (2005). GInaFit, a freeware tool to assess non-log-linear microbial survivor curves. International Journal of Food Microbiology, 102, 95-105.

Goodson, M., \& Rowbury, R, J. (1989). Habituation to normally lethal acidity by prior growth of Escherichia coli at a sub-lethal acid pH value. Letters in Applied Microbiology, $8,77-79$.

Guzel-Seydim, Z., Bever, P., \& Greene, A.K. (2004). Efficacy of ozone to reduce bacterial populations in the presence of food components. Food Microbiology, 21, 475479.

Herendeen, S. L., Vanbogelen, R. A., \& Neidhardt, F. F. (1979). Levels of major proteins of Escherichia coli during growth at different temperatures. Journal of Bacteriology, 139, 185-194. 
Hsin-Yi, C., \& Chou, C. C. (2001). Acid adaptation and temperature effect on the survival of E-coli O157: $\mathrm{H} 7$ in acidic fruit juice and lactic fermented milk product. International Journal of Food Microbiology, 70, 189-195.

Hunt, N.K., \& Marinas, B.J. (1997). Kinetics of Escherichia coli inactivation with ozone. Water Research, 31, 1355-1362.

Johnson, E. A. (2003). Microbial adaptation and survival in foods. In Yousef and Juneja, Microbial Stress adaptation and Food Safety. (pp 84-85). CRC press.

Jones, P. G., \& Inouye, M. (1994). The cold shock response- a hot topic. Molecular Microbiology, 11, 811-818.

Khadre, M.A., Yousef, A.E., \& Kim, J. G. (2001). Microbiological aspects of ozone. Applications in food: a review. Journal of Food Science, 66, 1242-1252.

Kim, J.G., Yousef, A.E., \& Dave, S. (1999). Application of ozone for enhancing the microbiological safety and quality of foods: A review. Journal of Food Protection, 62(9), 1071-1087.

Komanapalli, I. R., \& Lau, B. H. S. (1998). Inactivation of bacteriophage $\lambda$, Escherichia coli and Candida albicans by ozone. Applied Microbiology Biotechnology, 49, 766-769. Koutsoumanis, K. P., \& Sofos, J. N. (2004). Comparative acid stress response of Listeria monocytogenes, Escherichia coli O157:H7 and Salmonella typhimurium after habituation at different $\mathrm{pH}$ conditions. Letters in Applied Microbiology, 38, 321-326.

Kroll, R. G., \& Patchett, R. A. (1992). Induced acid tolerance in Listeria monocytogenes. Letters in Applied Microbiology, 14(5), 224-227. 
Leyer, G. J., Wang, L. L., \& Johnson, E. A. (1995). Acid adaptation of Escherichia coli O157:H7 increases survival in acidic foods. Applied and Environmental Microbiology, $61,3752-3755$.

Mielcke, J., \& Ried, A. (2004). Current state of application of ozone and UV for food processing. In proceedings of the food protection international conference 2004. Monte de Caparica, Portugal, 20-22 May 2004.

Muthukumarappan K., O’Donnell, C., \& Cullen, P. J. (2008). Ozone utilization. Encyclopedia of Agricultural, Food, and Biological Engineering, 1-4.

Pascual, A., Liorca, I.,\& Canut, A. (2007). Use of ozone in food industries for reducing the environmental impact of cleaning and disinfection activities. Trends in Food Science and Technology, 18, S29-S35.

Patil, S., Cullen, P. J., Kelly, B., Frias, J. M., \& Bourke, P. (2009). Extrinsic control parameters for ozone inactivation of Escherichia coli using ozone bubble column. Journal of Applied Microbiology, doi:10.1111/j.1365-2672.2009.04255.x.

Restaino, L., Frampton, E. W., Hemphill, J. B., \& Palnikar, P. (1995). Efficacy of ozonated water against various food-related microorganisms. Applied and Environmental Microbiology, 61(9), 3471-3475.

Rowe, M. T., \& Kirk, R. (1999). An investigation into the phenomenon of crossprotection in Escherichia coli O157:H7. Food Microbiology, 16, 157-164.

Shinoda, Y., Murata, M., Homma, S., \& Komura, H. (2004). Browning and decomposed products of model orange juice. Bioscience Biotechnology and Biochemistry, 68, 529536. 
Tiwari, B. K., O’ Donnell, C. P., Muthukumarappan, K., \& Cullen, P.J. (2009) Anthocyanin and colour degradation in ozone treated blackberry juice. Innovative Food Science and Emerging Technologies, 10, 70-75.

United States Food and Drug Administration (USFDA). (2001). Hazard analysis and critical point (HACCP); procedures for the safe and sanitary processing and importing of juice; final rule. Federal Register, 66, 6137-6202.

van Boekel, M. A. J. S. (2002) On the use of the Weibull model to describe thermal inactivation of microbial vegetative cells. International Journal of Food Microbiology, 74 (1-2), 139-159.

Vojdani, J., Beuchat, L., \& Tauxe, R. (2008). Juice-associated outbreaks of human illness in the United States, 1995 through 2005. Journal of Food protection, 71(2), 356-364.

Williams, R., Sumner, S., \& Golden, D. (2005). Inactivation of Escherichia coli O157:H7 and Salmonella in apple cider and orange juice treated with combinations of ozone, dimethyl dicarbonate, and hydrogen peroxide. Journal of Food Science, 70(4), 197-201. Williams, R., Sumner, S., \& Golden, D. (2004). Survival of Escherichia coli O157:H7 and Salmonella in apple cider and orange juice as affected by ozone and treatment temperature. Journal of Food Protection, 67(11), 2381-2386.

Yousef, A. E., \& Courtney, P. (2003). Basics of stress adaptation and implications in new-generation foods. In Yousef and Juneja, Microbial Stress adaptation and Food Safety. (pp-1-30). CRC press. 


\section{Figure Captions}

Figure 1: Schematics of Ozone generator

Figure 2: Microbial survival curve of Escherichia coli ATCC 25922 for the different orange juice types. Curves are fitted using the Weibull model.

Figure 3: Microbial survival curve of Escherichia coli NCTC 12900 for the different orange juice types. Curves are fitted using the Weibull model.

Figure 4: Microbial survival curve of acid exposed Escherichia coli strains of the reduced pulp orange juice (1mm sieve size).

. Curves are fitted using the Weibull model.
a) 1h acid exposed Escherichia coli ATCC 25922
b) $18 \mathrm{~h}$ acid exposed Escherichia coli ATCC 25922
c) 1h acid exposed Escherichia coli NCTC 12900
d) 18h acid exposed Escherichia coli NCTC 12900 
1 Table 1: Parameters of the Weibull model and the time required to reach a 5 log reduction for Escherichia coli strains in orange juice

2 after treatment with ozone (Different letters indicate a significant difference at the 0.05 level between each juice type for each strain

3 and between both strains for each juice type.)

\begin{tabular}{|c|c|c|c|c|c|c|}
\hline Microorganism & Juice type & Condition & $\delta(\min ) \pm \mathrm{SE}$ & $\mathrm{p} \pm \mathrm{SE}$ & $\mathrm{R}^{2}$ & $t_{5 d}(\min )$ \\
\hline E.coli ATCC 25922 & $\begin{array}{l}\text { Unfiltered } \\
1 \mathrm{~mm} \text { sieve } \\
500 \mu \mathrm{m} \text { sieve } \\
\text { Without pulp }\end{array}$ & $\begin{array}{l}\text { control } \\
\text { control } \\
\text { control } \\
\text { control }\end{array}$ & $\begin{array}{l}1.58^{\mathrm{a}} \pm 0.84 \\
3.28^{\mathrm{b}} \pm 0.33 \\
2.77^{\mathrm{c}} \pm 0.39 \\
2.91^{\mathrm{d}} \pm 0.35\end{array}$ & $\begin{array}{l}0.80^{\mathrm{f}} \pm 0.16 \\
2.98^{\mathrm{g}} \pm 0.49 \\
3.14^{\mathrm{g}} \pm 0.73 \\
3.26^{\mathrm{g}} \pm 0.69\end{array}$ & $\begin{array}{l}0.96 \\
0.98 \\
0.97 \\
0.98\end{array}$ & $\begin{array}{c}11.86^{\mathrm{k}} \\
5.62^{1} \\
4.63^{\mathrm{m}} \\
4.76^{\mathrm{m}}\end{array}$ \\
\hline E.coli NCTC 12900 & $\begin{array}{l}\text { Unfiltered } \\
1 \mathrm{~mm} \text { sieve } \\
500 \mu \mathrm{m} \text { sieve } \\
\text { Without pulp }\end{array}$ & $\begin{array}{l}\text { control } \\
\text { control } \\
\text { control } \\
\text { control }\end{array}$ & $\begin{array}{l}2.55^{\mathrm{ea}} \pm 0.91 \\
3.24^{\mathrm{eb}} \pm 0.43 \\
3.12^{\mathrm{e}} \pm 0.26 \\
3.41^{\mathrm{e}} \pm 0.55\end{array}$ & $\begin{array}{l}1.08^{\mathrm{hf}} \pm 0.21 \\
2.52^{\mathrm{ig}} \pm 0.52 \\
2.81^{\mathrm{j}} \pm 0.35 \\
4.44^{\mathrm{j}} \pm 1.81\end{array}$ & $\begin{array}{l}0.98 \\
0.97 \\
0.98 \\
0.93\end{array}$ & $\begin{array}{c}11.30^{\mathrm{nk}} \\
6.14^{\mathrm{ol}} \\
5.53^{\mathrm{p}} \\
4.90^{\mathrm{pm}}\end{array}$ \\
\hline
\end{tabular}

$4 *$ SE- standard error 
5 Table 2: Parameters of the Weibull model and the time required to reach a 5 log reduction for acid exposed Escherichia coli strains in

6 orange juice after treatment with ozone $(*$ Different letters indicate a significant difference at the 0.05 level between each juice type

7 for each strain and between both strains for each juice type.)

\begin{tabular}{|c|c|c|c|c|c|c|}
\hline Microorganism & Juice type & Condition & $\delta(\min ) \pm \mathrm{SE}$ & $\mathrm{p} \pm \mathrm{SE}$ & $\mathrm{R}^{2}$ & $t_{5 d}(\min )$ \\
\hline \multicolumn{7}{|c|}{ E.coli ATCC 25922} \\
\hline & $1 \mathrm{~mm}$ sieve & Control & $3.28^{\mathrm{a}} \pm 0.33$ & $2.98^{\mathrm{d}} \pm 0.49$ & 0.98 & $5.62^{h}$ \\
\hline & $1 \mathrm{~mm}$ sieve & 1h acid adapatation & $2.41^{\mathrm{b}} \pm 0.52$ & $1.63^{\mathrm{e}} \pm 0.31$ & 0.97 & $6.46^{\mathrm{i}}$ \\
\hline & $1 \mathrm{~mm}$ sieve & $18 \mathrm{~h}$ acid adaptation & $3.08^{\mathrm{a}} \pm 0.20$ & $2.63^{\mathrm{f}} \pm 0.25$ & 0.99 & $5.67^{\mathrm{h}}$ \\
\hline \multicolumn{7}{|c|}{ E.coli NCTC 12900} \\
\hline & $1 \mathrm{~mm}$ sieve & Control & $3.24^{\mathrm{ca}} \pm 0.43$ & $2.52^{\mathrm{gd}} \pm 0.52$ & 0.97 & $6.14^{\mathrm{jh}}$ \\
\hline & $1 \mathrm{~mm}$ sieve & $1 \mathrm{~h}$ acid adapatation & $2.49^{\mathrm{cb}} \pm 0.36$ & $1.81^{\mathrm{ge}} \pm 0.25$ & 0.98 & $6.06^{\mathrm{ji}}$ \\
\hline & $1 \mathrm{~mm}$ sieve & $18 \mathrm{~h}$ acid adaptation & $3.47^{\mathrm{ca}} \pm 0.37$ & $2.37^{\mathrm{gf}} \pm 0.35$ & 0.98 & $6.84^{\mathrm{j}}$ \\
\hline
\end{tabular}

$8 *$ SE- standard error 
10

11

12

13

14

15

16

17

18

19

20

21

22 Figure 1

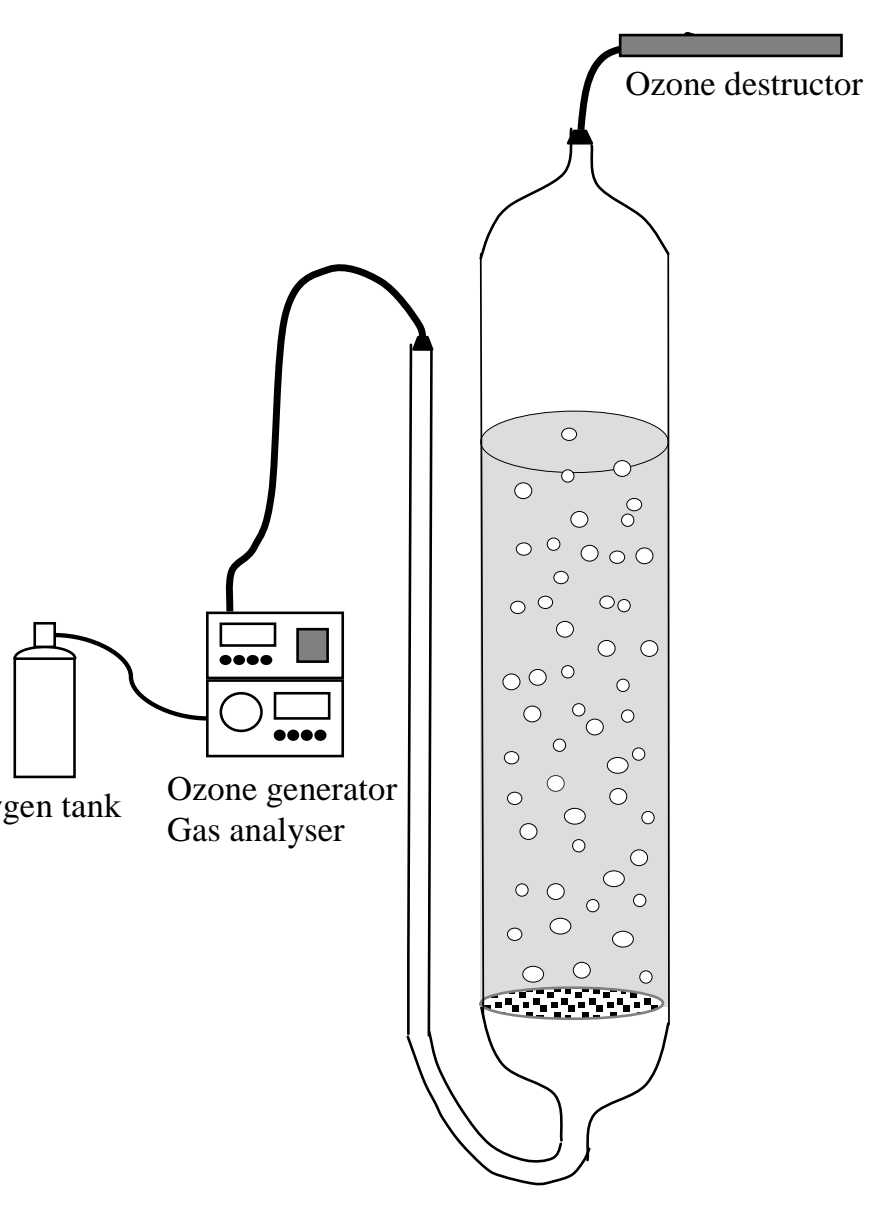

23

24

25

26

27

28

29

30

31 

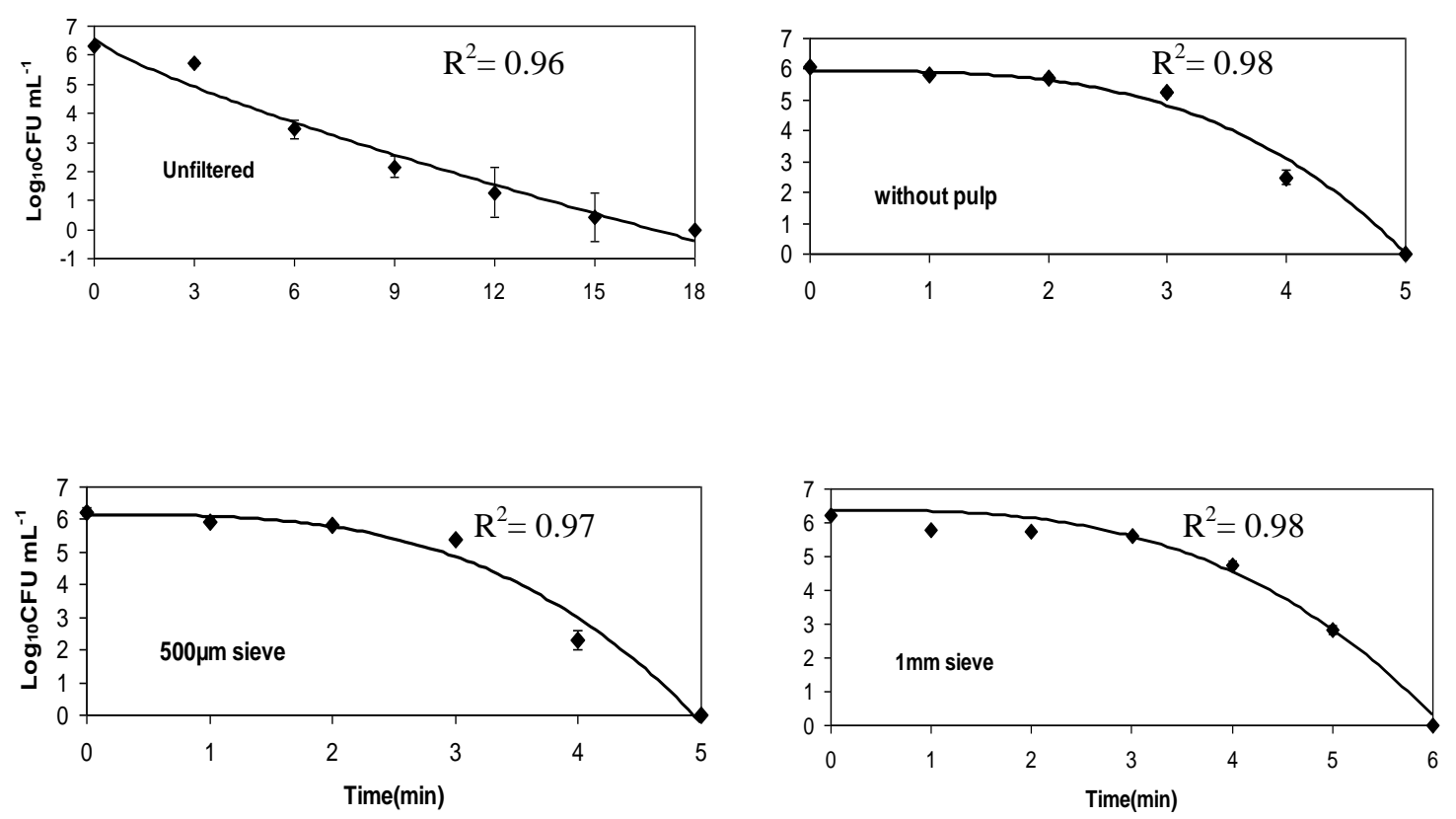

\section{$34 \quad$ Figure 2}



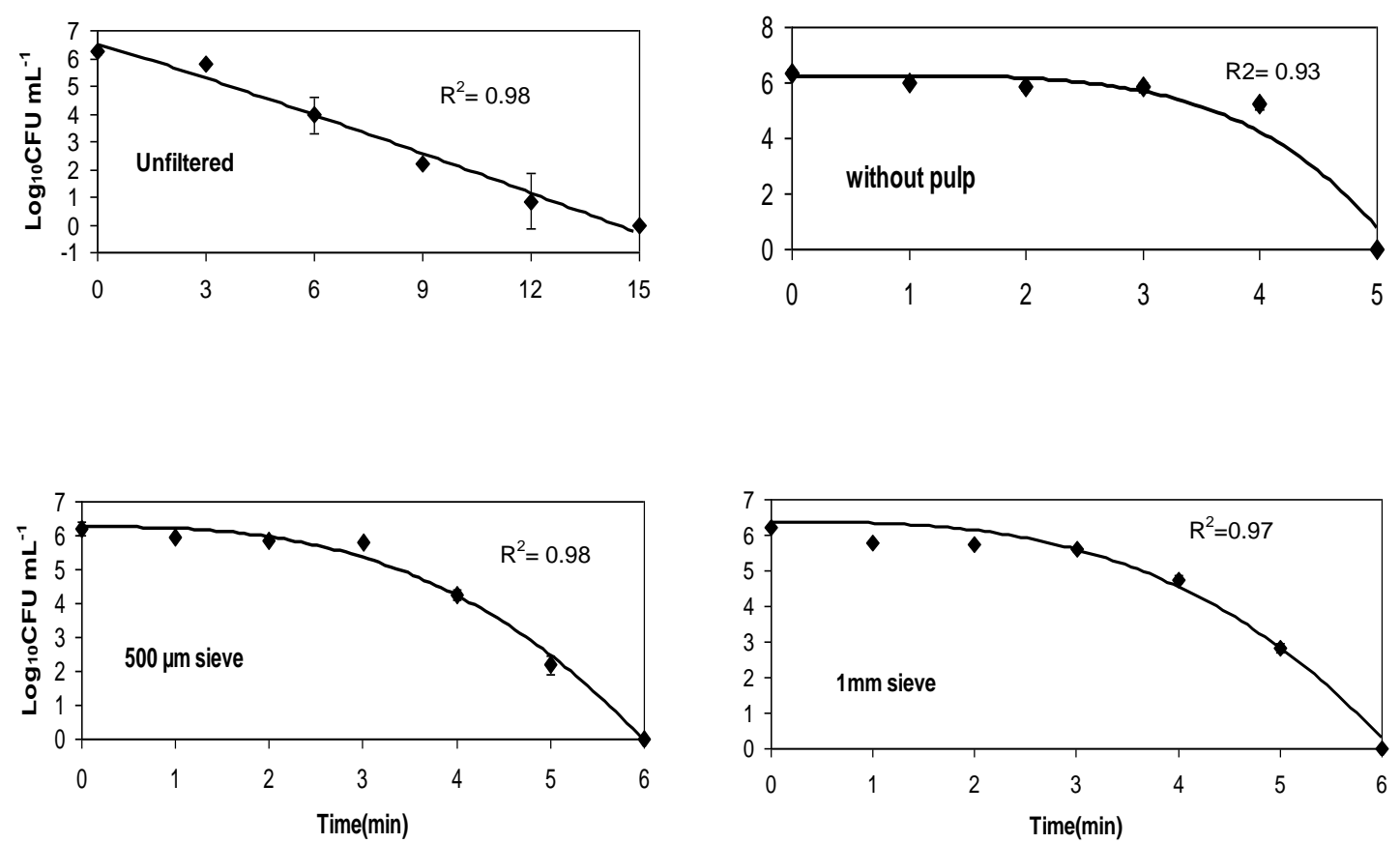

\section{$47 \quad$ Figure 3}




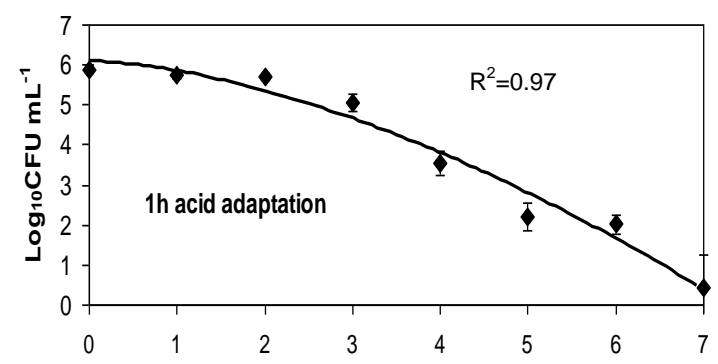

(a)

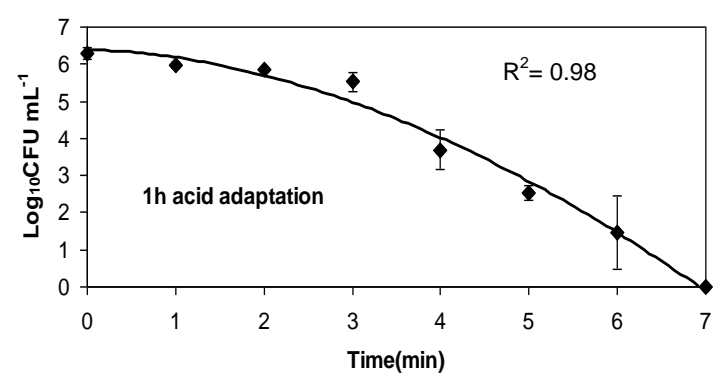

57

\section{$58 \quad$ Figure 4}

59

60

61

62

63

64

65

66

67

68

(c)

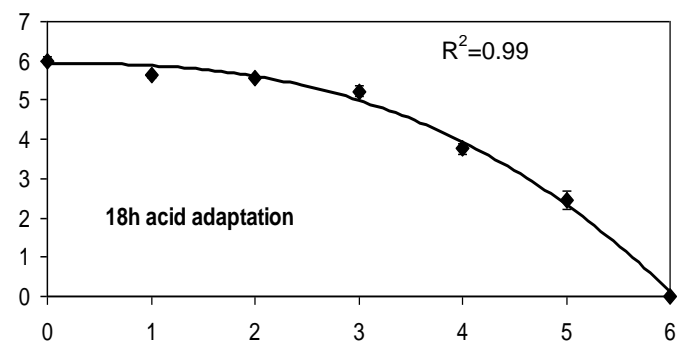

(b)

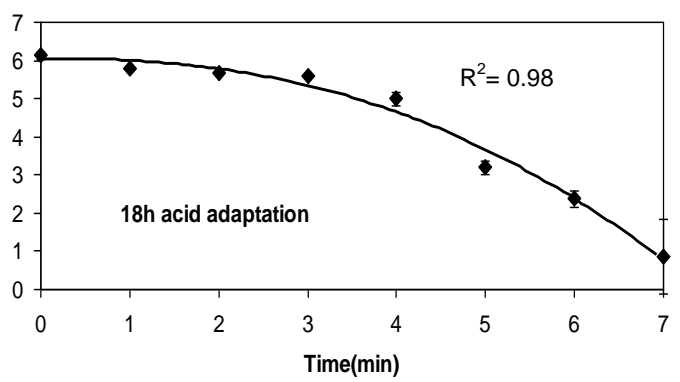

(d) 
